\title{
EFFECT OF INDUCED BIOLOGICAL FERMENTATIONS ON COFFEE SENSORY QUALITY
}

\author{
Talita Amparo Tranches Cândido ${ }^{1}$, Pedro Pereira Sepini², Polyana de Faria Cardoso Abrão ${ }^{3}$, \\ Reginaldo de Oliveira ${ }^{4}$, Kátia Alves Campos ${ }^{5}$, Leandro Carlos Paiva ${ }^{6}$
}

(Received: September 14, 2019; accepted: October 31, 2019)

\begin{abstract}
Quality coffee consumption has been gradually increasing and having an impact on coffee prices not only for domestic but also for the foreign market. Different processing (preparation) methods of coffee will directly influence the quality of the final product. Taking this into consideration, this study aimed at evaluating sensory attributes of coffee submitted to biological fermentation. The experiment was carried out in a block design with $4 \times 4+1$ factorial scheme. We evaluated the sensory attributes of coffee submitted to different fermentation treatments and times $(8,16,24,32$ hours submerged in water, water + Saccharomyces cerevisiae, water + Saccharomyces bayanus, and water + Lactococcus lactis $)$.
\end{abstract}

Index terms: specialty coffees, yeast, preparation, post-harvest, wet meal.

\section{INTRODUCTION}

Brazil is the largest producer and exporter of coffee worldwide. Production has been increasing year after year, so techniques for producing higher quality coffees should be improved and used, with the aim of reaching new markets, mainly for export.

Coffee quality is valued through sensory and organoleptic beverage properties. With increasing domestic coffee consumption, the search for quality has promoted great challenges in this sector (BORÉM, 2008). Coffee processing is an important post-harvest step to increase fruit homogeneity, avoiding possible drink quality shortcomings. Thus, choosing an ideal method depends mainly on farmer's economic capacity, amount produced, and intended quality standard (WINTGENS, 2004).

Beverage aroma is one of the factors that ensure coffee quality. This is due to the complexity of coffee bean compounds. The number of volatile compounds varies with bean processing system. In studying quality of coffee from different processing methods, Brando (1999) observed superior beverage characteristics for peeled, pulped, and mucilage removed coffees over natural one.

Coffee processing has become an important step in post-harvest. Separating green (immature) from cherry fruits is essential to achieve a superior quality beverage. For this purpose, the most different processing techniques are used (wet and dry) (WINTGENS, 2004). During coffee processing, gram-positive and gram-negative bacteria, yeast, and filamentous fungi are present throughout the different stages (MASOUD et al., 2004). As microorganisms are naturally present in all pre- and post-harvest stages, they may influence coffee beverage either by degradation of compounds in beans or by excretion of metabolites. In this sense, it is extremely important to characterize such microbiota through isolation and identification (REIS JÚNIOR et al., 2004).

Postharvest fermentation control avoids undesirable conditions that compromise beverage quality, decreasing coffee commercial value. If fermentation is optimally controlled and applied, superior and distinctive coffee beverages can be obtained, influencing the market and increasing acceptance of specialty coffees throughout the world.

Thus, this study aimed to evaluate the sensory beverage attributes for coffee induced to biological fermentation.

\section{MATERIAL AND METHODS}

The experiment was set and performed at IFSULDEMINAS, Campus Machado - MG ( $21^{\circ} 40^{\prime}$ S, $45^{\circ} 55^{\prime} \mathrm{W}, 850-\mathrm{m}$ altitude). A lot of arabica coffee (Mundo Novo variety) was collected at cherry stage. Beans were wetprocessed to obtain a maximum number of cherry grains, removing as much as possible of the raisins and buoys, maintaining increased homogeneity in treatments.

\footnotetext{
1,3,4Instituto Federal de Educação Ciência e Tecnologia do Sul de Minas - Campus Muzambinho - Estrada de Muzambinho, Km 35 Bairro Morro Preto - Cx. Postal 02 - Muzambinho-MG - 37890-000 - talitatranches@bol.com.br, pdf.cardoso@hotmail.com, romntb2019@gmail.com

${ }^{5,6}$ Instituto Federal de Educação Ciência e Tecnologia do Sul de Minas - Campus Machado Rod. Machado - Paraguaçu, Km 3 Bairro Santo Antônio - 37.750-000 - katia.campos@ifsuldeminas.edu.br, leandro.paiva@ifsuldeminas.edu.br

${ }^{2}$ Monte Alegre Coffes - Cx.P. 62 - Areado - MG - 37.140-000 - pedrosepini@gmail.com
} 
Yeasts were dosed and rehydrated, as recommended in the commercial product, and added in a sugar solution heated to $30^{\circ} \mathrm{C}$, to a ratio of number of living cells per amount of processed coffee (litres). About 160 litres of cherry coffee (natural) were processed. The harvested coffee lot was fractionated into 10 litres of coffee per treatment and isolated in clear plastic bags. Afterwards, yeasts were added, according to each treatment, then the bags were closed. The samples were transported to a suspended terrace where they were fermented during pre-established times. After reaching the estimated fermentation time, fermented samples were removed from the plastic bags and spread over the terrace for drying to $11-12 \%$ moisture, for later storage. The $\mathrm{pH}$ and temperature of must were monitored before sample removal, after reaching fermentation time.

Treatments consisted of different yeast strains, namely: water, water + Saccharomyces cerevisiae (Grand cru), water + Saccharomyces bayanus, water + Lactococcus lactis. Doses were figured out based on difficult fermentations, at different fermentation times, namely: 8, 16, 24, and $32 \mathrm{~h}$. In the experiment, an additional treatment was also worked. The coffee fruits were washed and subsequently dried, not going through the fermentation process, thus characterizing a randomized block experiment in an additional factorial scheme $(4 \mathrm{X} 4+1)$. Sensory analysis was performed by trained tasters.

It was intended to use an alternative multivariate technique to multiple analysis of univariate variances, that is, each of the seven response variables of the sensory analysis was not evaluated separately. The attributes evaluated by the tasters, aroma (X1), taste (X2), aftertaste (X3), acidity (X4), body (X5), balance (X6) and general (X7), were transformed into a single variable by means of Fisher's Discriminant Function (FISHER, 1936), as suggested by PimentelGomes (2009) and applied to coffee seedlings by Campos, Moraes and Paixão (2016).

Briefly, to find Fisher's Discriminant Function, the original characteristics are used to estimate a new variable by calculating the largest auto vector $\mathrm{t}$ which maximizes the ratio: ; wherein: $\mathrm{H}$ and $\mathrm{R}$ are respectively square sum matrices and treatment and residue effects. We estimated coefficients $\left(b_{i}\right)$ that define Fisher's linear discriminant function, which is described by Fisher's linear discriminant function $=\mathrm{b}_{1} \mathrm{X}_{1}+$ $\mathrm{b}_{2} \mathrm{X}_{2}+\mathrm{b}_{3} \mathrm{X}_{3}+\mathrm{b}_{4} \mathrm{X}_{4}+\mathrm{b}_{5} \mathrm{X}_{5}+\mathrm{b}_{6} \mathrm{X}_{6}+\mathrm{b}_{7} \mathrm{X}_{7}$; wherein:
$\mathrm{X}_{\mathrm{i}}$, with $\mathrm{i}=1, \ldots, 7$ and each characteristic as described above, and each $b_{i}$, with $i=1, \ldots, 7$, are coefficients determined by the proposed method. By substituting the observed values of each characteristic, a new variable is obtained Fisher's linear discriminant function (FISHER, 1936) - , which is capable of explaining much of the information in the characteristics.

After the transformation of the variables, the new variable had the assumptions of error normality and the homogeneity of variance of these transformed data were tested respectively by Shapiro-Wilks (1965) and Bartlett (1937) tests. After measured, scores were tabulated in spreadsheets, and with the aid of the R software, treatment means were calculated, and the F-test was applied $(\mathrm{p}<0.05)$ so that the additional treatment could be tested and compared to the others, as well as testing possible interactions between times and fermentation processes. For significant interactions, split analyses were performed, and means were compared by the Scott-Knott test $(\mathrm{p}<0.05)$ and by regression analysis.

\section{RESULTS AND DISCUSSION}

\section{Fisher's discriminant function (FDF)}

The assumptions of normality of errors and homogeneity of variances were met. Thus, the ANOVA applied to the data transformed by Fisher's discriminant function (FDF). There was a significant effect $(p<0.01)$ of time, fermentation, interaction, treatment, and block factors. This indicates a degree of confidence greater than $99 \%$ probability. Thus, we can state that all the factors had an effect on the characteristics under study. The coefficient of variation was $3.97 \%$, with small variation and dataset homogeneity.

By means of the values transformed by FDF, biplot graph (Figure 1) shows the two main components (CP1 and $\mathrm{CP} 2)$ and their respective variances. The first principal component (CP1) represents $90.45 \%$ and the second principal component (CP2) represents $9.3 \%$ of the total variance of FDF transformed data (Figure 1).

In CP1, there was a direct relationship of dependence between common fermentation and induced times of 16 and $32 \mathrm{~h}$. In contrast, there was an indirect relationship of dependence of the same treatment with the induced times of 24 and $8 \mathrm{~h}$.

There was also dependence between Grand cru and milk with the induced time of $8 \mathrm{~h}$. The treatment with water had a direct relationship with the induced time of $24 \mathrm{~h}$ and an inverse relationship with the induced times of 16 and $32 \mathrm{~h}$ (Figure 1). 
TABLE 1 - F-test for analysis of variance (ANOVA) of the treatments by Fisher's discriminant function (FDF).

\begin{tabular}{cccccc}
\hline VF & DF & SS & MS & F & p-value \\
\hline Time & 3 & 0.677296 & 0.225765 & $12.55^{* *}$ & $<0.001$ \\
Yeast & 3 & 0.412404 & 0.137468 & $7.64^{* *}$ & $<0.001$ \\
Interaction & 9 & 1.853352 & 0.205928 & $11.45^{* *}$ & $<0.001$ \\
Treatment & 16 & 2.943294 & 0.183956 & $10.23^{* *}$ & $<0.001$ \\
Block & 1 & 0.737216 & 0.737216 & $40.99^{* *}$ & $<0.001$ \\
Residue & 16 & 0.287759 & 0.017985 & & \\
Total & 33 & 3.968269 & & & $3.97 \%$ \\
CV & & & &
\end{tabular}

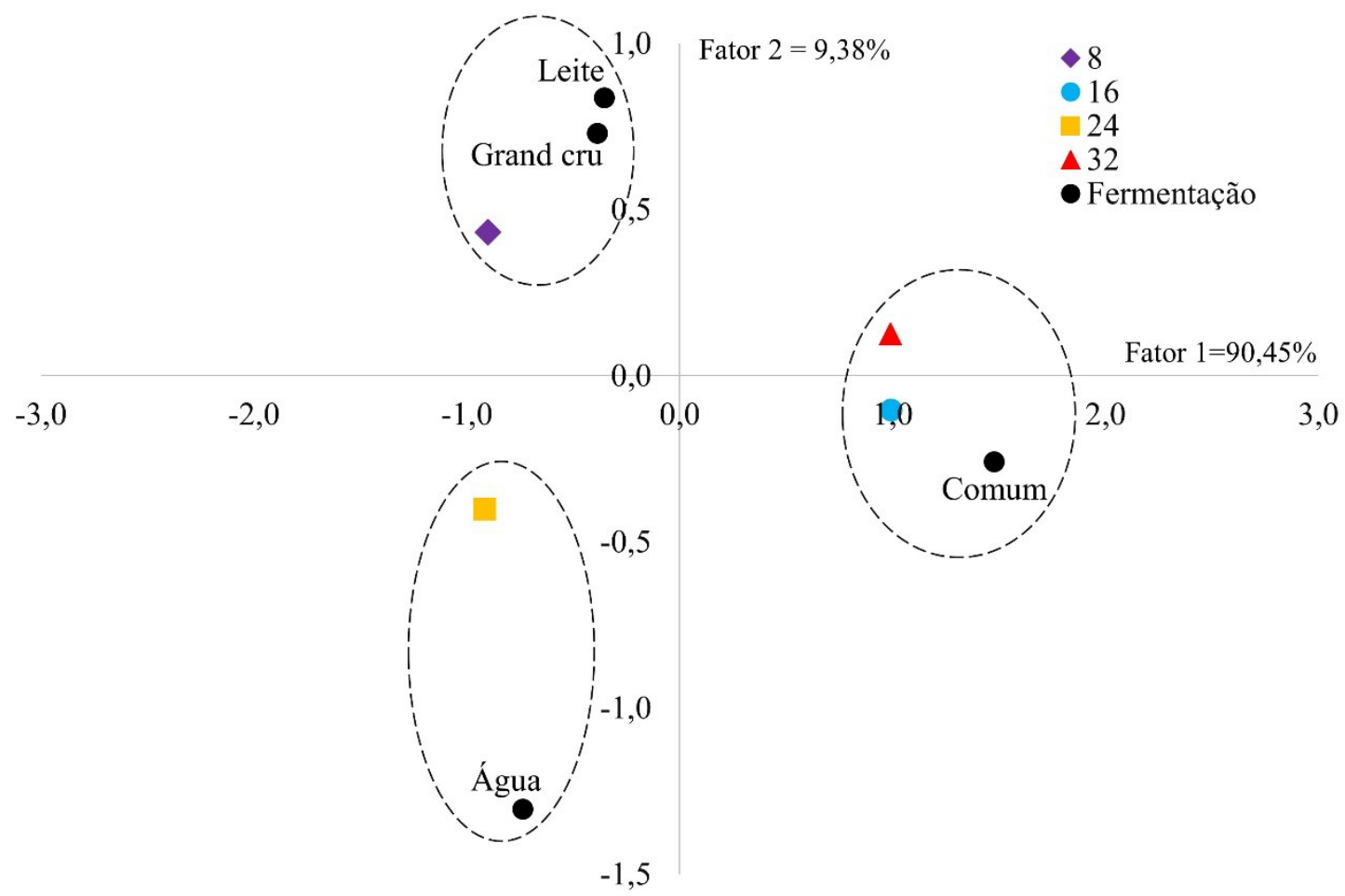

FIGURE 1 - Biplot plot between variables transformed by Fisher discriminant function (FDF), for fermentation and induced fermentation time, where milk refers s and water + Lactococcus lactis, Grand raw water + Saccharomyces bayanus, Common water + Saccharomyces cerevisae, and Water refers to fermentation without the addition of any strain.

The sensory analysis of coffee beverage quality by tasters (i.e., palate test) presented significant variations in terms of flavour, acidity, balance, and general traits. The additional treatment, which did not go through fermentation, had no significant effects on the studied parameters.

Through data transformed by FDF, we could notice a difference among tasters' performances, showing that from statistical combinations of a set of attributes, a single set can be built, with the same efficiency in the ranking.

Fermentation using water + Saccharomyces cerevisiae (common) should be determined by the induced times of 16 and $32 \mathrm{~h}$. Water + Saccharomyces bayanus (Grand cru), and water + Lactococcus lactis (milk) had improved beverage quality with an induced time of $8 \mathrm{~h}$. For water treatment, 8 and $24 \mathrm{~h}$ reached the highest scores. 


\section{CONCLUSION}

Given the above, we concluded that the best results were found for water + Saccharomyces cerevisiae (common) treatments with induced times of 16 and $32 \mathrm{~h}$; water + Saccharomyces bayanus (Grand cru) and water + Lactococcus lactis (milk) with a time of $8 \mathrm{~h}$ of fermentation, and only water with 8 and $24 \mathrm{~h}$ of fermentation induction.

\section{REFERENCES}

BARTLETT, M. S. Properties of sufficiency and statistical tests. Proceedings of the Royal Society of London, Series A, London, v. 160, n. 2, p. 268-282, 1937.

BORÉM, F. M. Pós-colheita do café. UFLA: Ed. UFLA, 2008.

CAMPOS, K. A., PAIXÃO, C. A., MORAIS, A. R. Alternative for evaluation of coffee seedlings using Fisher's discriminant analysis. Revista Ciência Agronômica. (UFC. Online), v. 47, p. 299, 2016.

FISHER, R. A. The use of multiple measurements in taxonomic problems. Annals of Eugenics, London, v. 7, n. 2, p. 179-188, 1936.
MASOUD, W.; CESAR. L. B.; JESPERSEN, L.; JAKOBSEN, M. Yeast involved in fermentation of Coffea Arabica in East Africa determined by genotyping and by direct denaturing gradient gel electrophoresis. New York, v. 21, n. 1, p. 549-556, 2004.

PIMENTEL-GOMES, F. Curso de estatística experimental. 15. ed. Piracicaba: FEALQ, 2009. 451 p. R Development Core Team. R: a language and environment for statistical computing. Vienna: $\mathrm{R}$ Foundation for Statistical Computing, 2012. Disponível em: <http://www.R-project.org>. Acesso em: 12 abr. 2019.

REIS JÚNIOR, F. B.; TEIXEIRA, K. R. dos S.; REIS, V. M. Análises de restrição do DNA Ribossomal Amplificado (ARDRA) em estudos de diversidade intra-específica de Azospirillum amazonense isolado de diferentes espécie de brachiaria. Distrito Federal: Embrapa Cerrados, 2004.

SHAPIRO, S. S.; WILK, M. B. An analysis of variance test for normality: complete samples. Biometrika, London, v. 52, n. 3/4, p. 591-611, Dec. 1965.

WINTGENS, J. N. Coffee: growing, processing, sustainable production. Weinheim: Oxford, 2004. 